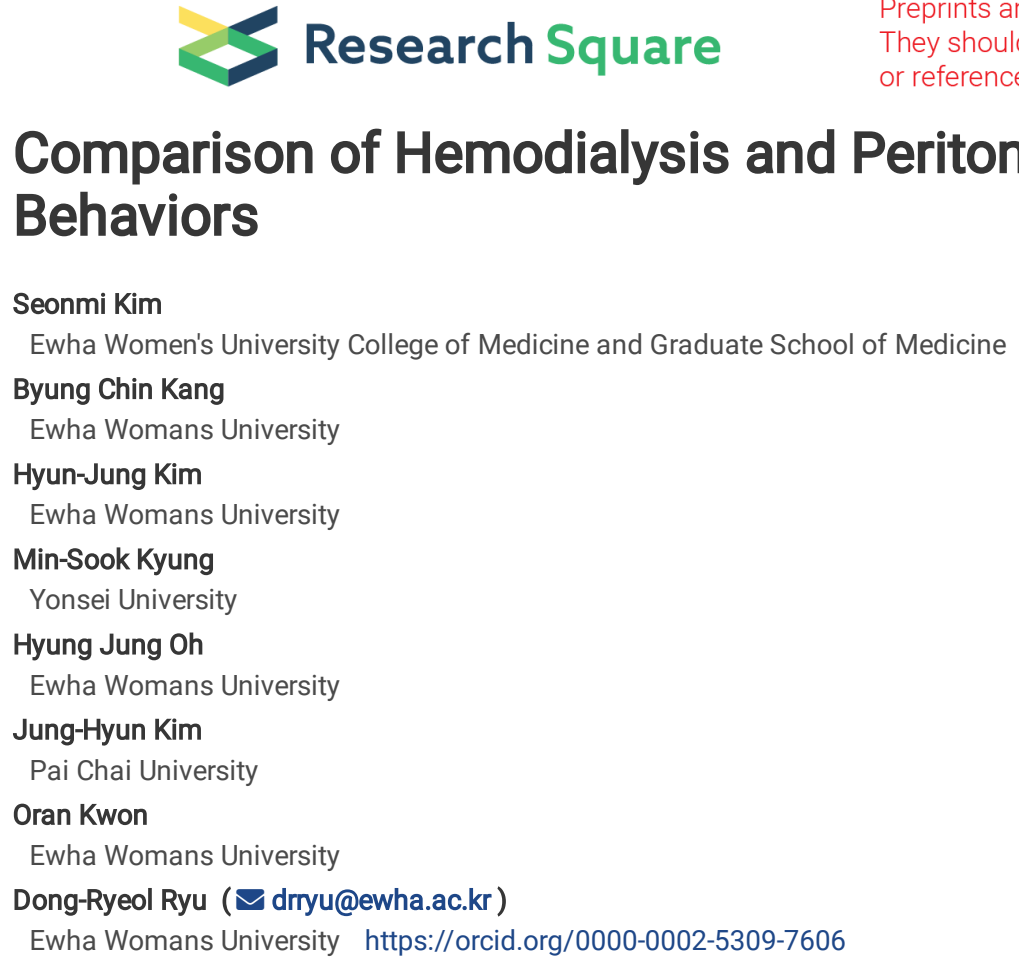

\title{
Comparison of Hemodialysis and Peritoneal Dialysis Patients' Dietary Behaviors
}




\section{Abstract}

Background: Nutritional factors are associated with high mortality and morbidity in dialysis patients, and protein-energy wasting is regarded as an important one. The modality of dialysis may affect patients' dietary behavior and nutritional status, but no study has compared the dietary behavior, nutrient intake, and nutritional adequacy of hemodialysis (HD) and peritoneal dialysis (PD) patients. Methods: From December 2016 to May 2017, a dietary behavior survey and Semi-quantitative Food Frequency Questionnaire (Semi-FFQ) were conducted, and laboratory parameters were obtained. The results of prevalent HD and PD patients were then compared. Results: In the dietary behavior survey, HD patients showed more appropriate dietary behavior patterns overall than PD patients. In the dietary intake analysis with the Semi-FFQ, energy intake was significantly lower in the PD group than in the HD group due to the lower intake of carbohydrates, fat, and protein. In the nutrient intake-to-recommended allowance ratio analysis, both HD and PD patients revealed inadequate intake amounts for most major nutrients. Serum albumin and potassium levels were significantly higher in HD than in PD patients. Serum albumin concentration showed a positive correlation with dietary protein and calcium intake in the PD group. Conclusion: According to this study, the dietary behavior and nutritional intake of prevalent PD patients were worse than those of HD patients.

\section{Background}

Patients reaching end-stage renal disease (ESRD) must decide between hemodialysis (HD) and peritoneal dialysis (PD) unless they are offered the opportunity to undergo kidney transplantation. Since the prognosis of ESRD according to dialysis modality is not significantly different, dialysis modality is mainly chosen after full consideration of both medical and non-medical factors, including patient preference and social factors [1].

The health status of dialysis patients is likely to be very poor; it was found to be as low as $54 \%$ of that of healthy individuals in Korea [2]. Among the factors associated with high mortality and morbidity in dialysis patients, protein-energy wasting (PEW) is regarded as an important one. PEW results from reduced dietary intake, inflammation, resistance to anabolic hormones, loss of nutrients during dialysis, gastrointestinal disturbance-induced medication (e.g., phosphate binders and iron supplements), and the breakdown of muscle protein induced by metabolic acidosis and comorbid conditions due to uremia [3]. The prevalence of PEW among maintenance HD patients varies from $18 \%$ to $56 \%$ [4-5]. In addition, PD patients are in a unique situation compared to HD patients: they experience similar net weekly nitrogen losses to HD patients despite protein loss of 6 to $8 \mathrm{~g} /$ day to peritoneal fluid [6] and on average 400 kcal of energy intake from obligatory glucose absorption [7]. Therefore, according to this dissimilarity in the nature of dialysis, dietary counseling usually differs for HD and PD. Unlike HD, PD is typically performed daily; thus, the body does not build up as much potassium, sodium, and fluid. Hence, most PD patients are recommended a diet that is more liberal than that of HD patients [8].

Consequently, HD and PD patients may have different diet patterns and differ in nutritional status. However, although a few studies have compared the nutritional status of HD and PD patients [9-11], no study has assessed and compared nutrient intake by the Semi-quantitative Food Frequency Questionnaire (Semi-FFQ) and dietary behavior according to dialysis modality. Thus, in this study, we investigated whether prevalent HD and PD patients' dietary behavior and nutrient intake differed.

\section{Methods}

\section{Subjects}

All eligible HD and PD patients of Ewha Womans University Mokdong Hospital, who voluntarily participated with written informed consent, were enrolled between December 2016 and May 2017. These patients were stable on dialysis for at least 3 months. We excluded patients who were younger than 18 years, had a plan for renal transplantation within 3 months, or had a life expectancy of less than 3 months. The study was performed in accordance with the Declaration of Helsinki and was approved by the Institutional Review Board of Ewha Womans University Medical Center (EUMC 2016-09-039-001).

\section{Data Collection}

Demographic and clinical data were recorded at the time of the study by a self-report survey and included sex, age, duration of dialysis, comorbidities, marital status, work status, family support, smoking, alcohol, and medication (including anti-hypertensive agents, phosphate binders, and supplemental iron). Patients with medications that were maintained for at least 2 months before enrollment were marked as having maintenance medication.

To detect PEW, we analyzed subjective global assessment (SGA), body mass index (BMI), mid-arm circumference, and hand grip strength. Nutritional status was determined using the 7-point SGA scale consisting of two categories: medical history and physical examination. The medical history section included weight change, dietary intake, gastrointestinal symptoms, functional capacity, and disease and comorbidity data. The physical examination section included loss of subcutaneous fat, muscle wasting, and edema. The trained investigators rated each item from 1 to 7 and decided the overall SGA score. Based on the overall SGA score, the patients were categorized into three groups: well nourished (normal) $=$ SGA score of $6-7$, mildly to moderately malnourished $=$ SGA score of $3-5$, or severely malnourished = SGA score of 1-2 [11]. HGS was measured in the hand without vascular access for HD patients and in the nondominant hand for PD patients.

Presence of diet education prior to dialysis initiation and experience of dietary support programs were also recorded. 
A questionnaire consisting of 10 items on the patient's appropriate or inappropriate dietary behaviors was used, which was a modified version of a questionnaire for dialysis patients from a previous study [12]. The questionnaire responses were divided into three categories according to the fulfillment frequency on each question: 0 to 2 days, 3 to 5 days, or 6 to 7 days during the week. For questions in which the number of days of appropriate diet activity for health was asked, we gave the scores 0,1 , and 2 for each response in order. In contrast, for questions in which the number of days of inappropriate diet activity for health was asked, we gave the scores 2,1 , and 0 for each response in order. Therefore, higher values represented better dietary behavior. The survey was conducted twice with an interval of more than 1 week, and the average values of the survey were used.

\section{SEMI-FFQ}

The Semi-FFQ is the most commonly used questionnaire in epidemiological studies to assess long-term nutritional exposure [13]. The Semi-FFQ examines the intake frequency during a standard period as well as the amount of the listed food categories. Recently, the Semi-FFQ has been used for the assessment of nutritional intake in dialysis patients [14]. In this study, a Semi-FFQ for Koreans was developed including 47 food items (Table S1), and the food items listed in the questionnaire were based on the Korean Health and Nutrition Survey. The Semi-FFQ consisted of groups of grains (rice, bread, and rice cake), meat, fish, beans, eggs, potatoes, dairy products, vegetables, and fruits classified as having low, medium, and high potassium content. The survey was conducted twice with an interval of more than 1 week, and the mean values were used.

\section{Laboratory Parameters}

The results of the most recent blood test within 1 month from the time of the survey were collected retrospectively. Blood samples were taken mid-week before the HD session for HD patients and on the outpatient visit day for PD patients. We measured the concentrations of serum albumin, blood urea nitrogen (BUN), creatinine, hemoglobin, hematocrit, sodium, phosphorus, calcium, potassium, and serum glucose.

\section{Statistical Analysis}

The results of the food intake amount and the frequency were analyzed by applying the nutrient evaluation program CAN-Pro 4.0. We analyzed the intake amounts for 20 nutrients, using the ninth revision of the National Standard Food Composition Table published by the Rural Development Administration in Korea [15]. In addition, the intake of each nutrient was compared to the recommended nutrient reference value [16].

The general characteristics, dietary behaviors, laboratory parameters, and Semi-FFQ scores of the subjects were presented as mean and standard deviation or $\mathrm{N}(\%)$, and $p$-value $<0.05$ was considered significant. For the comparison of the characteristics of the HD and PD groups, Student's t-test and the chi-square test were used. Statistical analyses were conducted using the SPSS statistical package for Windows Ver. 23.0 (SPSS, Inc., Chicago, IL, USA).

\section{Results}

\section{General Characteristics}

The clinical characteristics of subjects are shown in Table 1. The mean age of HD patients was higher than that of PD patients; HD: 58.5 \pm 9.1 years, PD: $49.3 \pm 9.7$ years $(p=0.001)$. The duration of dialysis was not significantly different between the two groups. We also compared the anthropometric value of

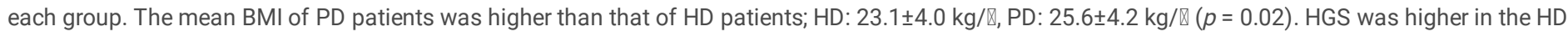

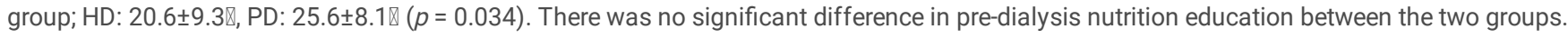

\section{Dietary Behaviors}

The results of dietary behaviors, obtained using the self-report questionnaire, are shown in Table 2. There were significant differences between the two groups in 6 out of 10 items about eating habits. The frequency of eating three meals a day (Question No. 1) was significantly higher in the HD group than in the PD group; HD: $1.45 \pm 0.62$, PD: $0.82 \pm 0.84(p=0.002)$. In addition, the frequency of intake of milk (Question No. 4), sugary food (Question No. 8-1), and fried food (Question No. 8-2); consideration of amount of drinking water (Question No. 9); and eating out (Question No. 10) was higher in the HD group than the PD group.

\section{Comparisons of Nutritional Intake and Nutritional Intake-to-recommended Allowance Ratio According to Dialysis Modality}

The results of the Semi-FFQ are shown in Table 3. Intake of energy, carbohydrates, fat, dietary fiber, water, vitamin E, vitamin C, thiamin, riboflavin, niacin, vitamin $B_{6}$, folic acid, pantothenic acid, calcium, phosphorus, sodium, and potassium was higher in HD patients than PD patients.

We also compared nutrient intake to recommended dietary allowance for dialysis patients [16.17]. The intake of most of the major nutrients (i.e., energy, carbohydrates, fat, protein, dietary fiber, water, vitamin C, thiamine, riboflavin, niacin, folic acid, pantothenic acid, and calcium) was lower than the 
recommended amount in both the $H D$ and PD groups. The nutrients with intakes over the recommended allowance were vitamin $E$, vitamin $B_{6}$, vitamin $B_{12}$, phosphorus, sodium, potassium, and cholesterol in the $\mathrm{HD}$ group and vitamin $\mathrm{B}_{6}$, vitamin $\mathrm{B}_{12}$, sodium, and cholesterol in the PD group.

\section{Laboratory Data}

Data on serum albumin, BUN, creatinine, hemoglobin, hematocrit, sodium, phosphorus, calcium, potassium, and serum glucose are shown in Table 4. Serum albumin and potassium levels were significantly higher in HD patients than in PD patients. Except for serum albumin and potassium, there were no significant differences in the laboratory findings between the HD and PD groups.

\section{Discussion}

In this study, we compared the dietary behaviors and nutrient intake of prevalent HD and PD patients and found that PD patients had worse dietary behaviors and lower dietary intake compared to HD patients. In addition, the ratio of moderately to severely malnourished patients was slightly higher in the PD group than the HD group. Serum albumin and potassium levels were significantly lower in the PD group than the HD group.

The proportion of patients whose nutritional status deteriorated from well-nourished to malnourished or remained as malnourished for 1 year after the start of dialysis treatment was higher in the PD group than the HD group [11]. The changes in nutritional status assessed by SGA during the first year were associated with mortality in incident ESRD patients. In this study, PD patients had poorer dietary behaviors and subsequently less sufficient dietary intake compared to HD patients. It is associated with widespread malnutrition among PD patients, and it may be responsible for the overall higher mortality in PD patients than HD patients [18].

To investigate the nutritional status of participants, we evaluated SGA, BMI, MAC, and HGS [19]. SGA is a well-established tool to assess nutritional status and a feasible method to ascertain PEW [20-21]. There were four (13.3\%) moderately to severely malnourished PD patients, while none of the HD patients was moderately to severely malnourished. BMI was higher in PD patients compared to HD patients, and MAC was not different between the two groups. In particular, HGS was significantly higher in PD patients than in HD patients, and we surmised that it was associated with the lower age of PD patients.

A recent study revealed that the nutritional status of $\mathrm{HD}$ and PD groups differs according to the dialysis vintage [22]. The dialysis duration $<2$ years is associated with better hydration, nutritional state, and survival in PD patients, but longer dialysis duration reduces the benefits of the PD group. Dialysis vintage $>4$ years is associated with similar hydration and mortality in both PD and HD groups. In this study, the mean duration of dialysis was $4-5$ years in both groups. Therefore, considering the dialysis vintage of the patients included in this study, the higher proportion of malnourished patients in the PD group could have been expected.

Next, we compared the dietary behaviors of the HD and PD groups. In the dietary behavior survey, HD patients scored higher than PD patients on most of the questions, which means that the HD group had better dietary behaviors than the PD group. Although HD patients tend to skip their meal on the day of HD, we need to pay attention to the lower rate of eating three meals a day in PD patients. Poor appetite, which is frequently seen in PD patients [23], may be one of the reasons for this. In addition, PD patients' intake of sugary or fried foods, which are usually recommended for sufficient energy intake in dialysis patients, was less than that of HD patients.

In the analysis of dietary intake using the Semi-FFQ, the HD group exhibited significantly higher consumption of dietary carbohydrates, dietary fat, dietary protein, and micronutrients than the PD group. A comparison of nutrient intake-to-recommended allowance ratio between the HD and PD groups [24-27] revealed that the HD group showed higher nutrient intake than the PD group.

The energy intake-to recommended allowance ratio in both HD and PD patients was low, and it was more prominent in the PD group than the HD group. However, considering energy intake from dialysate glucose [28], it is likely that the total energy intake of the PD group was similar to that of the HD group. A previous study comparing the nutritional status of HD and PD groups in Korea suggested that the HD group became malnourished due to a lack of energy intake and the PD group developed malnutrition due to a lack of protein intake [29]. In other words, intraperitoneal glucose absorption in dialysis fluid provides energy supplementation, but loss of protein through peritoneal fluid is more crucial for the development of malnutrition in PD patients. Based on the intake-torecommended allowance ratio for dialysis patients, the rate of protein intake was $76.6 \%$ for the HD group and $81.7 \%$ for the PD group without statistically significant differences, which means that both HD and PD groups took less than the recommended amount in this study.

PEW is associated with mortality in patients with ESRD on maintenance HD [30], and this study also confirmed poor energy consumption by both HD and PD patients. In non-dialysis CKD patients, a neutral or slightly positive nitrogen balance can be maintained with a low-protein ( $0.6-0.8 \mathrm{~g} / \mathrm{kg} / \mathrm{day})$ diet and restricted intake of sodium, potassium, and phosphorus [31-32]. In patients on maintenance HD and PD, however, their protein requirement is as high as 1.2$1.3 \mathrm{~g} / \mathrm{kg} /$ day [26] for the compensation of dialysis-related protein loss, extra energy expenditure, and persistent inflammation [33]. In this study, neither HD nor PD patients consumed adequate amounts of energy and protein compared to the recommended allowance. It should receive attention to ensure better outcomes and maintain high quality of life.

We also analyzed the laboratory parameters to assess nutrient status indirectly. Serum albumin levels were significantly higher in the HD group than the PD group, which is consistent with the results of previous studies [34]. The serum albumin value is considered a biomarker of visceral protein and a fundamental parameter of nutritional assessment [35]. We suggest that one of the reasons for the low serum albumin levels in the PD group is the significantly lower protein intake, which was revealed from the Semi-FFQ, and protein loss via PD fluid. Recent studies show that a low serum albumin level rather reflects a state 
of persistent inflammation and has limited value as a marker of nutritional status only [36]. Therefore, efforts to not only increase dietary protein intake but also reduce systemic inflammation are needed to increase serum albumin levels in PD patients.

In this study, serum potassium levels were significantly lower in the PD group than the HD group. The intake of dietary potassium in the HD group was slightly over the recommended allowance, but that in the PD group was less than $80 \%$ of the recommended intake. Therefore, the lower level of serum potassium in PD patients may be attributed to their low potassium intake reported in the Semi-FFQ. A recent study suggested that low serum potassium is an independent risk factor for mortality in dialysis patients, and the major cause of death in PD patients with lower potassium was cardiovascular death and infection [37].

This study has several limitations. First, we did not use a diet diary for a complete nutrient assay. Although the Semi-FFQ, which was used in this study, was validated elsewhere [38], a dietary record complements the Semi-FFQ and ensures the completeness of the nutrient survey. Second, we did not evaluate the nitrogen balance or precise inflammatory status of subjects. Third, this was a cross-sectional study, and the participants were not followed. Therefore, the clinical effects of dietary behaviors and nutrient intake could not be investigated due to the cross-sectional study design. Finally, a small number of patients were included in this study. Therefore, the statistical power was low.

\section{Conclusion}

According to this study, nutritional status, dietary behaviors, and nutrient intake-to-recommended allowance ratio were worse in PD patients compared to HD patients. Therefore, closer monitoring and proper interventions for maintaining healthy nutritional status are warranted in prevalent PD patients.

\section{Abbreviations}

ESRD: End-stage renal disease, HD: hemodialysis, PD: Peritoneal dialysis, PEW: Protein-energy wasting, Semi-FFQ: Semi-quantitative Food Frequency Questionnaire, SGA: Subjective global assessment, MAC: Mid-arm circumference, HGS: Hand grip strength, BMI: body mass index, BUN: Blood urea nitrogen

\section{Declarations}

\section{Ethics approval and consent to participate}

This study was approved by the Institutional Review Board of Ewha Womans University Medical Center (EUMC 2016-09-039-001). All participants' gave written informed consent before enrolment.

\section{Consent for publication}

All the authors gave their consent for the publication of this article.

\section{Availability of data or materials}

The dataset used in the analysis is available with the corresponding author and will be released on request.

\section{Competing interests}

There is no financial or non-financial competing interest.

\section{Funding}

This research funded by the Ministry of Health \& Welfare, Republic of Korea [grant number: HC15C1129].

\section{Authors' contributions}

JHK, OK and DRR were involved in study design. Protocol writing, review and amendments were done by SMK, BCK, HJK, MSK, and DRR. BCK, HJK, JHK, and DRR participated in data collection. BCK, HJK, and MSK were involved in laboratory analysis of samples. Data analysis was done by SMK, BCK, JHK, OK, and DRR. First draft of manuscript was prepared by SMK and BCK. All authors reviewed and approved the manuscript.

\section{Acknowledgements}

This research was supported by the Korea Health Technology R\&D Project through the Korea Health Industry Development Institute (KHIDI).

\section{References}

1. Chan CT, Blankestijn PJ, Dember LM et al. Dialysis initiation, modality choice, access, and prescription: conclusions from a Kidney Disease: Improving Global Outcomes (KDIGO) Controversies Conference. Kidney Int. 2019; 96(1):37-47.

2. Ryu DR, Kim YJ, Sul AR, et al. Outcomes research of peritoneal dialysis and hemodialysis for end-stage renal disease. National Evidence-based Healthcare Collaborating Agency; 2017(6): 1-260.

3. Carrero JJ, Stenvinkel P, Cuppari L, et al. Etiology of the protein-energy wasting syndrome in chronic kidney disease: a consensus statement from the International Society of Renal Nutrition and Metabolism (ISRNM). J Ren Nutr. 2013; 23(2):77-90.

4. Han SH, Han DS. Nutrition in patients on peritoneal dialysis. Nat Rev Nephrol. 2012; 8(3):163-75. 
5. Ruperto M, barril G, Sánchez-Muniz FJ. Prevalence of protein energy wasting in hemodialysis patients. Characterization of nutritional indicators and inflammatory markers. Atherosclerosis. 2014; 235(2):e242.

6. Yeun JY, Kaysen GA. Acute phase proteins and peritoneal dialysate albumin loss are the main determinants of serum albumin in peritoneal dialysis patients, Am J Kidney Dis. 1997; 30(6):923-7.

7. Burkart J. Metabolic consequences of peritoneal dialysis. Semin Dial. 2004; 17(6):498-504.

8. de Luis Román D, Bustamante J. Nutritional aspects in renal failure. Nefrologia. 2008; 28(3):333-42.

9. Jager KJ, Merkus MP, Huisman RM, et al. Nutritional status over time in hemodialysis and peritoneal dialysis. J Am Soc Nephrol. 2001; 12(6):1272-9.

10. Devolder I, Verleysen A, Vijt D, Vanholder R, Van Biesen W. Body composition, hydration, and related parameters in hemodialysis versus peritoneal dialysis patients. Perit Dail Int. 2010; 30(2):208-14.

11. Kwon YE, Kee YK, Yoon CY, et al. Change of Nutritional Status Assessed Using Subjective Global Assessment Is Associated With All-Cause Mortality in Incident Dialysis Patients. Medicine. 2016; 95(7):e2714.

12. Kim JH, Lee MJ, Moon SJ, et al. Ecological Analysis of Food Behavior and Life-Styles Affecting the Prevalence of Depression in Korea. Korean J Nutr. 1993; 26(9):1129-37.

13. Hong S, Choi Y, Lee HJ, et al. Development and validation of a semi-quantitative food frequency questionnaire to assess diets of korean type 2 diabetic patients. Diabetes Metab J. 2010; 34(1):32-9.

14. Kalantar-Zadeh K, Kovesdy CP, Bross R, et al. Design and development of a dialysis food frequency questionnaire. J Ren Nutr. 2011; 21(3):257-62.

15. Park SH, Kim SN, Lee SH, Choe JS, Choi Y. Development of 9th Revision Korean Food Composition Table and Its Major Changes. Korean J Community Nutr. 2018;23(4):352-65.

16. Beto JA, Bansal VK. Medical nutrition therapy in chronic kidney failure: integrating clinical practice guidelines. J Am Diet Assoc. 2004; 104(3):404-9.

17. John T. Daugirdas, Peter G, Blake MB. Book of dialysis. Philadelphia, PA: Wolters Kluwer Health; 2015.

18. Kim H, Kim KH, Park K, et al. A population-based approach indicates an overall higher patient mortality with peritoneal dialysis compared to hemodialysis in Korea. Kidney Int. 2014; 86(5):991-1000.

19. Leal VO, Stockler-Pinto MB, Farage NE, et al. Handgrip strength and its dialysis determinants in hemodialysis patients. Nutrition. 2011; 27(11-12):1125-9.

20. Steiber A, Leon JB, Secker D, et al. Multicenter study of the validity and reliability of subjective global assessment in the hemodialysis population. $J$ Ren Nutr. 2007; 17(5):336-42.

21. Detsky AS, McLaughlin JR, Baker JP, et al. What is subjective global assessment of nutritional status? J Parenter Enteral Nutr. 1987; 11(1):8-13.

22. Hoppe K, Schwermer K, Kawka A, et al. Dialysis vintage stratified comparison of body composition, hydration and nutritional state in peritoneal dialysis and hemodialysis patients. Arch Med Sci. 2018; 14(4):807-17.

23. Young V, Balaam S, Orazio L, et al. Appetite predicts intake and nutritional status in patients receving peritoneal dialysis. J Ren Care. 2016; $42(2): 123-31$.

24. Ash S, Campbell K, MacLaughlin H, et al. Evidence based practice guidelines for the nutritional management of chronic kidney disease. Nutrition \& Dietetics. 2006; 63(Suppl 2):S33-S45.

25. Wiggins KL, Harvey KS. A review of guidelines for nutrition care of renal patients. J Ren Nutr. 2002; 12(3):190-6.

26. Kopple JD. National kidney foundation K/DOQI clinical practice guidelines for nutrition in chronic renal failure. Am j Kidney Dis. 2001; 37 Suppl 2:S66-70.

27. Cano N, Fiaccadori E, Tesinsky P, et al. ESPEN Guidelines on Enteral Nutrition: Adult renal failure. Clin Nutr. 2006; 25(2):295-310.

28. Grodstein GP, Blumenkrantz MJ, Kopple JD, Moran JK, Coburn JW. Glucose absorption during continuous ambulatory peritoneal dialysis. Kidney Int. 1981; 19(4):564-7.

29. Kim SH, Kim SB. Characteristics in Nutritional Status of Patients on Hemodialysis and Continuous Ambulatory Peritoneal Patients in Chonbuk Area. Korean J Nutr. 2003; 36(4):397-404.

30. Kang SS, Chang JW, Park Y. Nutritional Status Predicts 10-Year Mortality in Patients with End-Stage Renal Disease on Hemodialysis. Nutrients. 2017; 9 (4).

31. Kalantar-Zadeh K, Fouque D. Nutritional Management of Chronic Kidney Disease. N Engl J Med. 2017; 377(18):1765-76.

32. Tom K, Young VR, Chapman T, Masud T, Akpele L, Maroni BJ. Long-term adaptive responses to dietary protein restriction in chronic renal failure. Am J Physio. 1995; 268(4 Pt 1):E668-77.

33. Kalantar-Zadeh K, Block G, McAllister CJ, Humphreys MH, Kopple JD. Appetite and inflammation, nutrition, anemia, and clinical outcome in hemodialysis patients. Am J Clin Nutr. 2004; 80(2):299-307.

34. Bovio G, Esposito C, Montagna G, et al. Inadequate Macronutrient and Micronutrient Intakes in Hemodialysis and Peritoneal Dialysis Patients: Data from a Seven-Day Weighed Dietary Record. Nephron. 2016; 133(4):253-60.

35. Friedman AN, Fadem SZ. Reassessment of albumin as a nutritional marker in kidney disease. J Am Soc Nephrol. 2010; 21(2):223-30.

36. Gama-Axelsson T, Heimburger O, Stenvinkel P, Barany P, Lindholm B, Qureshi AR. Serum albumin as predictor of nutritional status in patients with ESRD. Clin J Am Soc Nephrol. 2012; 7(9):1446-53.

37. Lee S, Kang E, Yoo KD, et al. Lower serum potassium associated with increased mortality in dialysis patients: A nationwide prospective observational cohort study in Korea. PLoS One. 2017; 12(3):e0171842.

38. Ryu DR, Kim JH, Kim HJ, Kyung MS, Park JT. Comparison Between Semi-Quantitative Frequency Methods and 7-day Dietary Records Methods in Food and Nutrition Intake Status For Hemodialysis Patients. Korean J Community Nutr. 2017 
Tables

Table 1. General characteristics of patients

\begin{tabular}{|c|c|c|c|c|c|c|c|c|c|}
\hline \multirow[t]{2}{*}{ Variables } & \multirow{2}{*}{$\begin{array}{c}\text { HD } \\
(n=30)\end{array}$} & \multirow[t]{2}{*}{$\mathrm{PD}(\mathrm{n}=30)$} & \multirow{2}{*}{$\begin{array}{c}p- \\
\text { value }\end{array}$} & \multicolumn{3}{|c|}{ HD $(n=30)$} & \multicolumn{3}{|c|}{$\mathrm{PD}(\mathrm{n}=30)$} \\
\hline & & & & $\begin{array}{c}\text { Male } \\
(\mathrm{n}=19)\end{array}$ & $\begin{array}{c}\text { Female } \\
(\mathrm{n}=11)\end{array}$ & $\begin{array}{c}p- \\
\text { value }\end{array}$ & $\begin{array}{c}\text { Male } \\
(\mathrm{n}=17)\end{array}$ & $\begin{array}{l}\text { Female } \\
(\mathrm{n}=13)\end{array}$ & $\begin{array}{c}p- \\
\text { value }\end{array}$ \\
\hline Age(years) & $58.5 \pm 9.1$ & $49.3 \pm 9.7$ & $0.001^{*}$ & $\begin{aligned} & 57.6 \\
\pm & 10.6\end{aligned}$ & $60.1 \pm 5.6$ & 0.405 & $\begin{array}{l}51.7 \pm \\
9.4\end{array}$ & $46.3 \pm 9.6$ & 0.138 \\
\hline $\begin{array}{l}\text { Duration of Dialysis } \\
\text { (months) }\end{array}$ & $\begin{array}{l}50.9 \pm \\
52.3\end{array}$ & $\begin{array}{c}63.4 \pm \\
56.4\end{array}$ & 0.377 & $\begin{array}{c}48.2 \\
\pm 59.6\end{array}$ & $55.7 \pm 38.7$ & 0.709 & $\begin{array}{l}55.8 \pm \\
55.4\end{array}$ & $73.5 \pm 58.4$ & 0.404 \\
\hline Comorbidities & & & & & & & & & \\
\hline $\begin{array}{l}\text { Yes } \\
\text { No }\end{array}$ & $\begin{array}{c}30(100.0) \\
0(0.0)\end{array}$ & $\begin{aligned} & 29(96.67) \\
& 1(3.33)\end{aligned}$ & 0.313 & $\begin{array}{c}19(100.0) \\
0(0.0)\end{array}$ & $\begin{array}{c}13(100.0) \\
0(0.0)\end{array}$ & NA & $\begin{array}{c}16(94.1) \\
1(5.9)\end{array}$ & $\begin{array}{c}13(100.0) \\
0(0.0)\end{array}$ & 0.374 \\
\hline Marital status & & & & & & & & & \\
\hline $\begin{array}{l}\text { Yes } \\
\text { No }\end{array}$ & $\begin{array}{l}24(80.0) \\
6(20.0)\end{array}$ & $\begin{array}{l}20(66.7) \\
10(33.3)\end{array}$ & 0.076 & $\begin{array}{l}14(73.7) \\
5(26.3)\end{array}$ & $\begin{aligned} 10 & (90.9) \\
1 & (9.1)\end{aligned}$ & 0.265 & $\begin{array}{l}11(64.7) \\
6(35.3)\end{array}$ & $\begin{array}{l}9(69.2) \\
4(30.8)\end{array}$ & 0.184 \\
\hline Work status & & & & & & & & & \\
\hline Yes & $6(20.0)$ & $16(53.3)$ & $0.007^{*}$ & $6(31.6)$ & $0(0.0)$ & $0.037^{*}$ & $11(64.7)$ & $5(38.5)$ & 0.153 \\
\hline No & $24(80.0)$ & $14(46.7)$ & & $13(68.4)$ & $11(100.0)$ & & $6(35.3)$ & $8(61.5)$ & \\
\hline Family support & & & & & & & & & \\
\hline $\begin{array}{l}\text { Yes } \\
\text { No } \\
\text { No response }\end{array}$ & $\begin{array}{c}26(86.7) \\
3(10.0) \\
1(3.3)\end{array}$ & $\begin{array}{l}26(86.7) \\
3(10.0) \\
1(3.3)\end{array}$ & 1.000 & $\begin{array}{l}16(84.2) \\
2(10.5) \\
1(5.3)\end{array}$ & $\begin{array}{l}10(52.6) \\
1(5.3) \\
0(0.0)\end{array}$ & 0.862 & $\begin{array}{l}15(88.2) \\
2(11.6) \\
0(0.0)\end{array}$ & $\begin{aligned} 11 & (84.6) \\
1 & (7.7) \\
1 & (7.7)\end{aligned}$ & 0.794 \\
\hline Smoking & & & & & & & & & \\
\hline $\begin{array}{l}\text { Yes } \\
\text { No }\end{array}$ & $\begin{array}{c}2(6.7) \\
28(93.3)\end{array}$ & $\begin{array}{l}3(10.0) \\
27(90.0)\end{array}$ & 0.640 & $\begin{array}{c}2(10.5) \\
17(89.5)\end{array}$ & $\begin{array}{c}0(0.0) \\
11(100.0)\end{array}$ & 0.265 & $\begin{array}{l}3(17.7) \\
14(82.4)\end{array}$ & $\begin{array}{c}0(0.0) \\
13(100.0)\end{array}$ & 0.110 \\
\hline Alcohol & & & & & & & & & \\
\hline Yes & $0(0.0)$ & $2(6.7)$ & 0.150 & $0(0.0)$ & $0(0.0)$ & NA & $1(5.9)$ & $1(7.7)$ & 0.844 \\
\hline No & $30(100.0)$ & $28(93.3)$ & & $19(100.0)$ & $11(100.0)$ & & $16(94.1)$ & $12(92.3)$ & \\
\hline Taking any medication & & & & & & & & & \\
\hline Yes & 29 (96.7) & $29(96.7)$ & NA & $18(94.7)$ & $11(100.0)$ & NA & $16(94.1)$ & $13(100.0)$ & NA \\
\hline No & $0(0.0)$ & $1(5.3)$ & & $0(0.0)$ & $0(0.0)$ & & $1(5.9)$ & $0(0.0)$ & \\
\hline No response & $1(5.3)$ & $0(0.0)$ & & $1(5.3)$ & $0(0.0)$ & & $0(0.0)$ & $0(0.0)$ & \\
\hline Anti-hypertensive & & & & & & & & & \\
\hline Yes & $23(76.7)$ & $27(90.0)$ & 0.166 & $14(73.7)$ & $9(47.4)$ & 0.612 & $\begin{array}{c}17 \\
(100.0)\end{array}$ & $10(76.9)$ & $0.037^{*}$ \\
\hline $\begin{array}{l}\text { No } \\
\text { Phosphate binders }\end{array}$ & 7 (23.3) & $3(10.0)$ & & $5(26.3)$ & $2(18.2)$ & & $0(0.0)$ & $3(23.1)$ & \\
\hline Yes & $27(90.0)$ & $28(93.3)$ & 0.640 & $16(84.2)$ & $11(100.0)$ & 0.165 & $15(88.2)$ & $13(100.0)$ & 0.201 \\
\hline No & $3(10.0)$ & $2(6.7)$ & & $3(15.8)$ & $0(0.0)$ & & $2(11.8)$ & $0(0.0)$ & \\
\hline Supplemental iron & & & & & & & & & \\
\hline Yes & $26(86.7)$ & $25(83.3)$ & 0.718 & $16(84.2)$ & $10(90.9)$ & 0.603 & $14(82.4)$ & $11(84.6)$ & 0.869 \\
\hline No & $4(13.3)$ & $5(16.7)$ & & $3(15.8)$ & $1(9.1)$ & & $3(17.6)$ & $2(15.4)$ & \\
\hline Subjective global assessment & & & & & & & & & \\
\hline Normal & $12(44.0)$ & $12(40.0)$ & 0.143 & $8(42.1)$ & $4(36.4)$ & 0.519 & $8(47.1)$ & $4(30.8)$ & 0.346 \\
\hline Mild malnourished & $15(50.0)$ & $14(46.7)$ & & $9(47.4)$ & $6(54.6)$ & & $8(47.1)$ & $6(46.2)$ & \\
\hline $\begin{array}{l}\text { Moderate to severe } \\
\text { malnourished }\end{array}$ & $0(0)$ & $4(13.3)$ & & $0(0)$ & $0(0)$ & & $1(5.9)$ & $3(23.1)$ & \\
\hline No response & $3(10.0)$ & $0(0)$ & & $2(10.5)$ & $1(9.1)$ & & $0(0)$ & $0(0)$ & \\
\hline Anthropometry & & & & & & & & & \\
\hline Body mass index $\left(\mathrm{kg} / \mathrm{m}^{2}\right)$ & $\begin{array}{c}23.08 \pm \\
3.99\end{array}$ & $\begin{array}{c}25.62 \pm \\
4.24\end{array}$ & $0.020^{*}$ & $\begin{array}{c}24.12 \pm \\
4.02\end{array}$ & $\begin{array}{c}21.28 \pm \\
3.99\end{array}$ & 0.059 & $\begin{array}{c}25.63 \pm \\
4.45\end{array}$ & $\begin{array}{c}25.60 \pm \\
4.12\end{array}$ & 0.985 \\
\hline Mid-arm circumference (cm) & $\begin{array}{c}28.63 \pm \\
5.01\end{array}$ & $\begin{array}{c}28.45 \pm \\
3.93\end{array}$ & 0.875 & $\begin{array}{c}30.07 \pm \\
5.28\end{array}$ & $\begin{array}{c}26.27 \pm \\
3.60\end{array}$ & $0.045^{*}$ & $\begin{array}{c}29.68 \pm \\
7.32\end{array}$ & $\begin{array}{c}20.26 \pm \\
5.70\end{array}$ & 0.348 \\
\hline Hand grip strength (kg) & $\begin{array}{c}20.63 \pm \\
9.26\end{array}$ & $\begin{array}{c}25.60 \pm \\
8.09\end{array}$ & $0.034^{*}$ & $\begin{array}{c}24.96 \pm \\
8.60\end{array}$ & $\begin{array}{c}13.93 \pm \\
5.64\end{array}$ & $0.001^{* *}$ & $\begin{array}{c}27.85 \pm \\
4.44\end{array}$ & $\begin{array}{c}29.23 \pm \\
3.14\end{array}$ & $0.001^{*}$ \\
\hline Pre-dialysis diet education & & & & & & & & & \\
\hline Yes & $27(90.0)$ & $30(100.0)$ & 0.206 & $16(84.2)$ & $11(92.3)$ & 0.165 & $\begin{array}{c}17 \\
(100.0)\end{array}$ & $13(100.0)$ & NA \\
\hline No & $3(10.0)$ & $0(0.0)$ & & $3(15.8)$ & $0(0.0)$ & & $0(0.0)$ & $0(0.0)$ & \\
\hline $\begin{array}{l}\text { Experience of dietary support } \\
\text { programs }\end{array}$ & & & & & & & & & \\
\hline Yes & $1(3.3)$ & $0(0.0)$ & 0.313 & $1(5.3)$ & $0(0.0)$ & 0.439 & $0(0.0)$ & $0(0.0)$ & NA \\
\hline No & $29(96.7)$ & $30(100.0)$ & & $18(94.7)$ & $11(100.0)$ & & $\begin{array}{c}17 \\
(100.0)\end{array}$ & $13(100.0)$ & \\
\hline
\end{tabular}

Data are presented as Mean \pm SD or $\mathrm{N}(\%)$.

NA: Not available due to small number of cases

$* p<0.05, * * p<0.001$

Table 2. Dietary behaviors of subjects 


\begin{tabular}{|c|c|c|c|c|c|c|c|c|c|}
\hline \multirow[t]{2}{*}{ Variables } & \multirow{2}{*}{$\begin{array}{c}\mathrm{HD} \\
(\mathrm{n}=30)\end{array}$} & \multirow{2}{*}{$\begin{array}{c}\mathrm{PD} \\
(\mathrm{n}=30)\end{array}$} & \multirow[t]{2}{*}{$p$-value } & \multicolumn{3}{|c|}{$\mathrm{HD}(\mathrm{n}=30)$} & \multicolumn{3}{|c|}{$\mathrm{PD}(\mathrm{n}=30)$} \\
\hline & & & & $\begin{array}{c}\text { Male } \\
(\mathrm{n}=19)\end{array}$ & $\begin{array}{l}\text { Female } \\
(\mathrm{n}=11)\end{array}$ & $\begin{array}{l}p- \\
\text { value }\end{array}$ & $\begin{array}{c}\text { Male } \\
(\mathrm{n}=17)\end{array}$ & $\begin{array}{l}\text { Female } \\
(\mathrm{n}=13)\end{array}$ & $p$-value \\
\hline $\begin{array}{l}\text { 1. How many days per week } \\
\text { do you have three meals a } \\
\text { day? }\end{array}$ & $1.45 \pm 0.62$ & $0.82 \pm 0.84$ & $0.002^{*}$ & $1.66 \pm 0.53$ & $1.09 \pm 0.63$ & $0.013^{*}$ & $1.21 \pm 0.9$ & $0.31 \pm 0.44$ & $<0.001^{* *}$ \\
\hline $\begin{array}{l}\text { 2. How many times per week } \\
\text { do you have meals with a } \\
\text { variety of grains fish, meat } \\
\text { and vegetables? }\end{array}$ & $1.07 \pm 0.63$ & $0.80 \pm 0.64$ & 0.108 & $1.05 \pm 0.71$ & $1.09 \pm 0.49$ & 0.875 & $0.94 \pm 0.7$ & $0.62 \pm 0.55$ & 0.170 \\
\hline $\begin{array}{l}\text { 3. How many times do you } \\
\text { have fruits per week? }\end{array}$ & $0.75 \pm 0.67$ & $0.85 \pm 0.65$ & 0.557 & $0.76 \pm 0.77$ & $0.73 \pm 0.47$ & 0.875 & $0.74 \pm 0.7$ & $1.00 \pm 0.5$ & 0.273 \\
\hline $\begin{array}{l}\text { 4. How many times do you } \\
\text { have milk per week? }\end{array}$ & $0.70 \pm 0.78$ & $0.27 \pm 0.57$ & $0.018^{*}$ & $0.74 \pm 0.84$ & $0.64 \pm 0.71$ & 0.741 & $0.24 \pm 0.6$ & $0.31 \pm 0.59$ & 0.736 \\
\hline $\begin{array}{l}\text { 5. Do you soak vegetables in } \\
\text { water or boil them to remove } \\
\text { potassium? }\end{array}$ & $1.20 \pm 0.78$ & $0.78 \pm 0.85$ & 0.053 & $1.13 \pm 0.93$ & $1.32 \pm 0.46$ & 0.469 & $0.79 \pm 0.9$ & $0.77 \pm 0.81$ & 0.938 \\
\hline $\begin{array}{l}\text { 6. How many times per week } \\
\text { do you have salted sea foods, } \\
\text { pickled vegetables, ham, } \\
\text { sausage canned fish, etc.? }\end{array}$ & $1.77 \pm 0.49$ & $1.50 \pm 0.74$ & 0.106 & $1.68 \pm 0.56$ & $1.91 \pm 0.3$ & 0.163 & $1.32 \pm 0.8$ & $1.73 \pm 0.59$ & 0.139 \\
\hline $\begin{array}{l}\text { 7. How many days per week } \\
\text { do you have } 2 \text { meals a day } \\
\text { with a dish of protein? }\end{array}$ & $0.68 \pm 0.64$ & $0.97 \pm 0.56$ & 0.071 & $0.58 \pm 0.71$ & $0.86 \pm 0.45$ & 0.192 & $1.27 \pm 0.5$ & $0.58 \pm 0.4$ & $<0.001^{* *}$ \\
\hline $\begin{array}{l}8-1 \text {. How many times per } \\
\text { week do you have sugary } \\
\text { foods for calorific } \\
\text { replenishment? }\end{array}$ & $0.88 \pm 0.64$ & $0.30 \pm 0.41$ & $<0.001^{* *}$ & $0.89 \pm 0.74$ & $0.86 \pm 0.45$ & 0.900 & $0.32 \pm 0.4$ & $0.27 \pm 0.39$ & 0.724 \\
\hline $\begin{array}{l}8-2 \text {. How many times per } \\
\text { week do you have fried foods } \\
\text { for calorific replenishment? }\end{array}$ & $0.75 \pm 0.58$ & $0.25 \pm 0.39$ & $<0.001^{* *}$ & $0.74 \pm 0.63$ & $0.77 \pm 0.52$ & 0.874 & $0.27 \pm 0.4$ & $0.23 \pm 0.39$ & 0.817 \\
\hline $\begin{array}{l}\text { 9. Do you consider the } \\
\text { amount of water needed to } \\
\text { consume every day? }\end{array}$ & $1.28 \pm 0.68$ & $0.87 \pm 0.68$ & $0.021^{*}$ & $1.26 \pm 0.71$ & $1.32 \pm 0.64$ & 0.835 & $0.88 \pm 0.7$ & $0.85 \pm 0.69$ & 0.888 \\
\hline $\begin{array}{l}10 . \text { How many times per } \\
\text { week do you eat out? }\end{array}$ & $1.58 \pm 0.66$ & $0.72 \pm 0.81$ & $<0.001^{* *}$ & $1.53 \pm 0.72$ & $1.68 \pm 0.56$ & 0.542 & $0.82 \pm 0.9$ & $0.58 \pm 0.76$ & 0.416 \\
\hline
\end{tabular}

Data are presented as Mean \pm SD.

${ }^{*} p<0.05,{ }^{* *} p<0.001$

Table 3. Nutrition intake and intake-to-recommended allowance ratio according to dialysis modality 


\begin{tabular}{|c|c|c|c|c|c|c|c|c|}
\hline \multirow[t]{2}{*}{ Variables } & \multirow[t]{2}{*}{$\mathrm{HD}(\mathrm{n}=30)$} & \multirow[t]{2}{*}{$\mathrm{PD}(\mathrm{n}=30)$} & \multirow[t]{2}{*}{$p$-value } & \multicolumn{3}{|c|}{ HD $(n=30)$} & \multicolumn{2}{|r|}{$\mathrm{PD}(\mathrm{n}=$} \\
\hline & & & & Male $(n=19)$ & Female $(\mathrm{n}=11)$ & $p$-value & Male $(n=17)$ & Fema \\
\hline $\begin{array}{l}\text { Energy (kcal) } \\
\text { (\%) }\end{array}$ & $\begin{array}{c}1547.45 \pm 380.83 \\
(79.8 \pm 26.1)\end{array}$ & $\begin{array}{c}1203.37 \pm 387.78 \\
(53.5 \pm 19.6)\end{array}$ & $\begin{array}{l}<0.001^{* *} \\
\left(<0.001^{* *}\right)\end{array}$ & $\begin{array}{c}1647.29 \pm 389.97 \\
(76.8 \pm 28.4)\end{array}$ & $\begin{array}{c}1375.00 \pm 308.55 \\
(85.0 \pm 21.9)\end{array}$ & $\begin{array}{c}0.016^{*} \\
(0.421)\end{array}$ & $\begin{array}{c}1280.3 \pm 450.08 \\
(54.8 \pm 23.4)\end{array}$ & $\begin{array}{r}1102 . \varepsilon \\
\quad(51 .\end{array}$ \\
\hline $\begin{array}{l}\text { Carbohydrate } \\
\text { (g) }\end{array}$ & $231.98 \pm 55.40$ & $176.87 \pm 54.66$ & $<0.001^{* *}$ & $245.53 \pm 57.53$ & $208.57 \pm 44.63$ & $0.030^{*}$ & $187.89 \pm 64.26$ & 162. \\
\hline$(\%)$ & $(95.7 \pm 31.2)$ & $(63.1 \pm 23.1)$ & $\left(<0.001^{* *}\right)$ & $(91.6 \pm 34.3)$ & $(102.8 \pm 25.0)$ & $(0.356)$ & $(64.6 \pm 28.0)$ & (61. \\
\hline Fat $(g)$ & $40.97 \pm 13.07$ & $32.75 \pm 12.71$ & $0.016^{*}$ & $43.78 \pm 13.74$ & $36.13 \pm 10.71$ & 0.118 & $33.83 \pm 13.64$ & 31.3 \\
\hline$(\%)$ & $(65.4 \pm 24.0)$ & $(45.0 \pm 18.7)$ & $\left(<0.001^{* *}\right)$ & $(62.7 \pm 24.4)$ & $(69.9 \pm 23.6)$ & $(0.437)$ & $(44.6 \pm 20.0)$ & (56. \\
\hline$(g)$ & $62.92 \pm 25.39$ & $50.60 \pm 19.65$ & $0.040^{*}$ & $67.50 \pm 29.45$ & $55.01 \pm 14.11$ & 0.167 & $54.72 \pm 22.91$ & 45.2 \\
\hline$(\%)$ & $(76.6 \pm 20.6)$ & $(81.7 \pm 16.6)$ & $(0.295)$ & $(85.1 \pm 20.4)$ & $(61.8 \pm 10.1)$ & $\begin{array}{c}( \\
\left.<0.001^{* *}\right)\end{array}$ & $(87.0 \pm 19.3)$ & (74 \\
\hline $\begin{array}{l}\text { Dietary Fiber } \\
(\mathrm{g})\end{array}$ & $15.92 \pm 4.51$ & $12.29 \pm 3.98$ & $0.002^{*}$ & $16.22 \pm 4.91$ & $15.41 \pm 3.89$ & 0.745 & $12.08 \pm 4.09$ & 12.5 \\
\hline & $(63.7 \pm 18.1)$ & $(49.2 \pm 15.9)$ & $\left(0.002^{*}\right)$ & $(64.9 \pm 19.7)$ & $(61.6 \pm 15.6)$ & $(0.642)$ & $(48.3 \pm 16.4)$ & (50. \\
\hline Water (ml) & $687.80 \pm 187.49$ & $552.4 \pm 176.31$ & $0.006^{*}$ & $716.23 \pm 197.47$ & $638.70 \pm 166.01$ & 0.295 & $558.19 \pm 190.52$ & 545.0 \\
\hline$(\%)$ & $(45.9 \pm 12.5)$ & $(36.8 \pm 11.8)$ & $\left(0.006^{*}\right)$ & $(47.8 \pm 13.2)$ & $(42.6 \pm 11.1)$ & $(0.283)$ & $(37.2 \pm 12.7)$ & (36. \\
\hline $\begin{array}{l}\text { Vitamin E } \\
\text { (mg) }\end{array}$ & $15.33 \pm 4.57$ & $10.7 \pm 3.78$ & $<0.001^{* *}$ & $15.57 \pm 4.97$ & $14.92 \pm 3.98$ & 0.538 & $10.84 \pm 3.86$ & 10.5 \\
\hline (\%) & $(102.2 \pm 30.5)$ & $(71.5 \pm 25.2)$ & $\left(<0.001^{* *}\right)$ & $(103.8 \pm 33.1)$ & $(99.4 \pm 26.5)$ & $(0.710)$ & $(72.3 \pm 25.8)$ & (70. \\
\hline $\begin{array}{l}\text { Vitamin C } \\
(\mathrm{mg})\end{array}$ & $89.86 \pm 38.42$ & $68.94 \pm 38.66$ & $0.040^{*}$ & $87.81 \pm 44.17$ & $93.41 \pm 27.31$ & 0.571 & $64.92 \pm 34.41$ & 74.1 \\
\hline$(\%)$ & $(99.9 \pm 42.7)$ & $(76.6 \pm 43.0)$ & $\left(0.040^{*}\right)$ & $(97.6 \pm 49.1)$ & $(103.8 \pm 30.4)$ & $(0.708)$ & $(72.1 \pm 38.2)$ & (82. \\
\hline $\begin{array}{l}\text { Thiamin (mg) } \\
(\%)\end{array}$ & $\begin{array}{c}0.97 \pm 0.33 \\
(80.7 \pm 27.6)\end{array}$ & $\begin{array}{c}0.81 \pm 0.28 \\
(67.3 \pm 23.3)\end{array}$ & $\begin{array}{l}0.046^{*} \\
\left(0.046^{*}\right)\end{array}$ & $\begin{array}{c}1.05 \pm 0.37 \\
(87.2 \pm 30.6)\end{array}$ & $\begin{array}{c}0.83 \pm 0.21 \\
(69.4 \pm 17.2)\end{array}$ & $\begin{array}{c}0.06 \\
(0.089)\end{array}$ & $\begin{array}{c}0.84 \pm 0.33 \\
(70.2 \pm 27.2)\end{array}$ & $\begin{array}{r}0.7 \\
(63 .\end{array}$ \\
\hline $\begin{array}{l}\text { Riboflavin } \\
\text { (mg) }\end{array}$ & $0.97 \pm 0.28$ & $0.79 \pm 0.24$ & $0.009^{*}$ & $1.00 \pm 0.29$ & $0.93 \pm 0.26$ & 0.251 & $0.82 \pm 0.27$ & 0.7 \\
\hline$(\%)$ & $(74.8 \pm 21.3)$ & $(60.7 \pm 18.6)$ & $\left(0.009^{*}\right)$ & $(76.7 \pm 22.5)$ & $(71.5 \pm 19.7)$ & $(0.535)$ & $(63.3 \pm 20.9)$ & (57. \\
\hline $\begin{array}{l}\text { Niacin (mg) } \\
(\%)\end{array}$ & $\begin{array}{l}13.31 \pm 4.84 \\
(83.2 \pm 30.3)\end{array}$ & $\begin{array}{l}10.77 \pm 3.62 \\
(67.3 \pm 22.7)\end{array}$ & $\begin{array}{l}0.025^{*} \\
\left(0.025^{*}\right)\end{array}$ & $\begin{array}{l}14.38 \pm 5.52 \\
(89.9 \pm 34.5)\end{array}$ & $\begin{array}{l}11.45 \pm 2.68 \\
(71.5 \pm 16.8)\end{array}$ & $\begin{array}{c}0.060 \\
(0.061)\end{array}$ & $\begin{array}{l}11.27 \pm 3.79 \\
(70.4 \pm 23.7)\end{array}$ & $\begin{array}{l}10.1 \\
(63 .\end{array}$ \\
\hline $\begin{array}{l}\text { Vitamin } B_{6} \\
(\mathrm{mg})\end{array}$ & $1.27 \pm 0.4$ & $1.03 \pm 0.35$ & $0.017^{*}$ & $1.36 \pm 0.45$ & $1.11 \pm 0.25$ & 0.088 & $1.05 \pm 0.37$ & 1.0 \\
\hline (\%) & $(292.4 \pm 166.0)$ & $(230.7 \pm 121.6)$ & $(0.106)$ & $(282.0 \pm 161.4)$ & $(310.5 \pm 180.0)$ & $(0.658)$ & $(254.5 \pm 109.8)$ & (199. \\
\hline $\begin{array}{l}\text { Folic acid } \\
(\mu g) \\
(\%)\end{array}$ & $400.5 \pm 102.59$ & $311.18 \pm 88.01$ & $<0.001^{* *}$ & $399.71 \pm 112.13$ & $402.07 \pm 88.8$ & 0.757 & $314.22 \pm 93.54$ & 307.2 \\
\hline $\begin{array}{l}\text { Vitamin } B_{12} \\
(\mu \mathrm{g})\end{array}$ & $7.02 \pm 3.98$ & $5.54 \pm 2.92$ & 0.106 & $\begin{array}{c}(40.0 \pm 11.2) \\
6.77 \pm 3.87\end{array}$ & $\begin{array}{l}(40.2 \pm 8.9) \\
7.45 \pm 4.32\end{array}$ & $\begin{array}{c}(0.953) \\
0.637\end{array}$ & $\begin{array}{l}(31.4 \pm 9.4) \\
6.11 \pm 2.63\end{array}$ & $\begin{array}{l}30 \\
4.7\end{array}$ \\
\hline$(\%)$ & $(292.4 \pm 166.0)$ & $(230.7 \pm 121.6)$ & ( & $(282.0 \pm 161.4)$ & $(310.5 \pm 180.0)$ & $(0.6$ & $(254.5 \pm 109.8)$ & (199. \\
\hline $\begin{array}{l}\text { Pantothenic } \\
\text { Acid (mg) }\end{array}$ & $4.33 \pm 1.18$ & $3.23 \pm 0.89$ & $<0.001^{* *}$ & $4.79 \pm 1.08$ & $3.54 \pm 0.90$ & $<0.001^{* *}$ & $3.49 \pm 0.95$ & 2.8 \\
\hline (\%) & $(86.6 \pm 23.5)$ & $(64.6 \pm 17.8)$ & $\left(<0.001^{* *}\right)$ & $(95.7 \pm 21.7)$ & $(70.7 \pm 18.1)$ & $\left(0.003^{*}\right)$ & $(69.9 \pm 19.0)$ & (57. \\
\hline Calcium (mg) & $394.58 \pm 128.42$ & $307.87 \pm 104.39$ & $0.006^{*}$ & $384.39 \pm 141.19$ & $412.19 \pm 106.79$ & 0.888 & $310.22 \pm 109.58$ & 304.8 \\
\hline$(\%)$ & $(19.7 \pm 6.4)$ & $(15.4 \pm 5.2)$ & $\left(0.006^{*}\right)$ & $(19.2 \pm 7.1)$ & $(20.6 \pm 5.3)$ & $(0.577)$ & $(15.5 \pm 5.5)$ & $(15$ \\
\hline $\begin{array}{l}\text { Phosphorus } \\
\text { (mg) }\end{array}$ & $840.45 \pm 253.64$ & $670.14 \pm 220.90$ & $0.007^{*}$ & $886.32 \pm 283.3$ & $761.20 \pm 176.61$ & 0.077 & $707.84 \pm 247.54$ & 620.8 \\
\hline$(\%)$ & $(105.1 \pm 31.7)$ & $(83.8 \pm 27.6)$ & $\left(0.007^{*}\right)$ & $(110.8 \pm 35.4)$ & $(95.2 \pm 22.1)$ & $(0.198)$ & $(88.5 \pm 30.9)$ & (77. \\
\hline Sodium (mg) & $3581.06 \pm 1235.23$ & $2675.09 \pm 818.76$ & $0.002^{*}$ & $3559.27 \pm 1257.9$ & $3618.69 \pm 1254.7$ & 0.297 & $2912.4 \pm 823.19$ & 2364.7 \\
\hline$(\%)$ & $(179.1 \pm 61.8)$ & $(133.8 \pm 40.9)$ & $\left(0.002^{*}\right)$ & $(178.0 \pm 62.9)$ & $(180.9 \pm 62.7)$ & $(0.902)$ & $(145.6 \pm 41.2)$ & (118 \\
\hline $\begin{array}{l}\text { Potassium } \\
\text { (mg) }\end{array}$ & $2100.44 \pm 600.58$ & $1602.47 \pm 509.12$ & $<0.001^{* *}$ & $2153.44 \pm 668.77$ & $2008.91 \pm 475.85$ & 0.487 & $1609.2 \pm 555.8$ & 1593.7 \\
\hline$(\%)$ & $(105.0 \pm 30.0)$ & $(80.1 \pm 25.5)$ & $\left(<0.001^{* *}\right)$ & $(107.7 \pm 33.4)$ & $(100.5 \pm 23.8)$ & $(0.497)$ & $(80.5 \pm 27.8)$ & (79. \\
\hline $\begin{array}{l}\text { Cholesterol } \\
\text { (mg) }\end{array}$ & $337.25 \pm 171.25$ & $259.14 \pm 130.88$ & 0.052 & $375.13 \pm 194.12$ & $271.83 \pm 98.9$ & $0.016^{*}$ & $295.03 \pm 141.29$ & 212.2 \\
\hline$(\%$ & $(169.5 \pm 86.1)$ & $(130.2 \pm 65.8)$ & $(0.052)$ & $(188.5 \pm 97.6)$ & $(136.6 \pm 49.7)$ & $(0.113)$ & $(148.3 \pm 71.0)$ & $(106$ \\
\hline
\end{tabular}

\footnotetext{
Data are presented as Mean \pm SD.
}

Intake-to-recommended allowance ratio analysis are presented in parentheses below the nutrition intake

$* p<0.05,{ }^{* *} p<0.001$ 
Table4. Comparison of laboratory findings

\begin{tabular}{|c|c|c|c|c|c|c|c|c|c|c|}
\hline \multirow[t]{2}{*}{ Variables } & \multirow{2}{*}{$\begin{array}{l}\text { Reference } \\
\text { range }\end{array}$} & \multirow{2}{*}{$\begin{array}{c}\text { HD } \\
(n=30)\end{array}$} & \multirow[t]{2}{*}{$\mathrm{PD}(\mathrm{n}=30)$} & \multirow[t]{2}{*}{$p$-value } & \multicolumn{3}{|c|}{$\mathrm{HD}(\mathrm{n}=30)$} & \multicolumn{3}{|c|}{$\mathrm{PD}(\mathrm{n}=30)$} \\
\hline & & & & & $\begin{array}{c}\text { Male } \\
(\mathrm{n}=19)\end{array}$ & $\begin{array}{l}\text { Female } \\
(\mathrm{n}=11)\end{array}$ & $\begin{array}{c}p- \\
\text { value }\end{array}$ & $\begin{array}{c}\text { Male } \\
(\mathrm{n}=17)\end{array}$ & $\begin{array}{l}\text { Female } \\
(\mathrm{n}=13)\end{array}$ & $\begin{array}{c}p- \\
\text { value }\end{array}$ \\
\hline Albumin & $3.5 \sim 5.0$ & $3.7 \pm 0.4$ & $3.4 \pm 0.4$ & $0.043^{*}$ & $3.6 \pm 0.4$ & $3.9 \pm 0.2$ & $0.032^{*}$ & $3.4 \pm 0.5$ & $3.6 \pm 0.3$ & 0.254 \\
\hline $\begin{array}{l}\text { BUN } \\
\text { (mg/dL) }\end{array}$ & $10 \sim 20$ & $64.9 \pm 19.7$ & $58.4 \pm 16.5$ & 0.169 & $62.1 \pm 18.2$ & $69.9 \pm 22.0$ & 0.299 & $65.3 \pm 15.0$ & $49.4 \pm 14.2$ & $0.007^{*}$ \\
\hline $\begin{array}{l}\text { Creatinine } \\
\text { (mg/dL) }\end{array}$ & $0.5 \sim 1.2$ & $12.7 \pm 15.0$ & $11.1 \pm 3.5$ & 0.561 & $14.5 \pm 18.8$ & $9.7 \pm 2.4$ & 0.412 & $12.4 \pm 3.6$ & $9.4 \pm 2.7$ & $0.020^{*}$ \\
\hline $\begin{array}{l}\text { Hemoglobin } \\
(\mathrm{g} / \mathrm{dL})\end{array}$ & $9 \sim 11.5$ & $10.4 \pm 1.0$ & $10.4 \pm 1.6$ & 0.883 & $10.5 \pm 1.0$ & $10.3 \pm 0.9$ & 0.460 & $10.3 \pm 1.9$ & $10.5 \pm 1.0$ & 0.651 \\
\hline $\begin{array}{l}\text { Hematocrit } \\
(\%)\end{array}$ & $37 \sim 52$ & $31.1 \pm 2.9$ & $30.9 \pm 4.7$ & 0.862 & $31.1 \pm 2.9$ & $31.1 \pm 2.8$ & 0.963 & $30.3 \pm 5.9$ & $31.7 \pm 2.8$ & 0.417 \\
\hline $\begin{array}{l}\text { Sodium } \\
\text { (mEq/L) }\end{array}$ & $136 \sim 145$ & $136.9 \pm 3.1$ & $137.0 \pm 3.9$ & 0.941 & $137.1 \pm 3.0$ & $136.7 \pm 3.5$ & 0.788 & $136.2 \pm 4.0$ & $138.1 \pm 3.6$ & 0.185 \\
\hline $\begin{array}{l}\text { Phosphorus } \\
\text { (mg/dL) }\end{array}$ & $3.0 \sim 4.5$ & $5.7 \pm 1.9$ & $5.8 \pm 1.6$ & 0.948 & $5.7 \pm 2.0$ & $5.8 \pm 1.9$ & 0.863 & $5.8 \pm 1.7$ & $5.8 \pm 1.6$ & 0.994 \\
\hline $\begin{array}{l}\text { Calcium } \\
\text { (mg/dL) }\end{array}$ & $9.0 \sim 10.5$ & $8.7 \pm 0.9$ & $8.6 \pm 0.8$ & 0.705 & $8.4 \pm 0.8$ & $9.1 \pm 0.9$ & 0.063 & $8.4 \pm 0.9$ & $8.8 \pm 0.8$ & 0.250 \\
\hline $\begin{array}{l}\text { Potassium } \\
(\mathrm{mEq} / \mathrm{L})\end{array}$ & $3.5 \sim 5.0$ & $5.1 \pm 0.7$ & $4.4 \pm 0.7$ & $<0.001^{* *}$ & $5.0 \pm 0.6$ & $5.5 \pm 0.8$ & 0.050 & $4.4 \pm 0.7$ & $4.5 \pm 0.7$ & 0.604 \\
\hline $\begin{array}{l}\text { Serum } \\
\text { glucose } \\
(\mathrm{mg} / \mathrm{dL})\end{array}$ & $70 \sim 110$ & $162.1 \pm 8.2$ & $131.6 \pm 95.1$ & 0.185 & $151.8 \pm 68.8$ & $179.7 \pm 98.0$ & 0.368 & $123.0 \pm 74.7$ & $142.9 \pm 119.0$ & 0.578 \\
\hline
\end{tabular}

\section{Supplementary Files}

This is a list of supplementary files associated with this preprint. Click to download.

- SupplementBMC.docx 